\title{
Grandparents Raising Grandchildren: School and Educational Assistance ${ }^{1}$
}

Maisie Ross, Larry Forthun, Millie Ferrer-Chancy, and Angela Falcone ${ }^{2}$

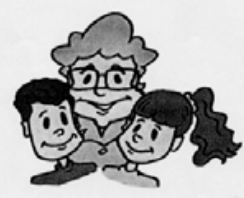

Goal: To provide information about education and afterschool care assistance to grandfamilies who are residents in the state of Florida.

\section{Early Childhood Education-School Readiness Program}

If you are working, volunteering, or otherwise unable to care for your younger grandchildren throughout the day, you may find it difficult to find quality child care. Florida's School Readiness program was created to address this need. Each community in the state is required to have an Early Learning Coalition that provides a placement office to assist parents and grandparents in finding quality child care and early education. The early learning office can also provide information about how to obtain financial assistance if you are unable to pay for child care on your own. Since eligibility and options may vary, you must call your local office for details. Visit the Early Learning Coalition Web site at http://www.floridajobs.org/earlylearning/Coalition Directory.htm for a directory of local offices; or call the Agency for Workforce Innovation's Office of Early Learning Child Care Resource Referral Network at 1-866-357-3239 (TTY: 711) for assistance.

\section{Head Start and Early Head Start are early} education programs for children up to age five. They are child-focused programs aimed at increasing the school readiness of young children in low-income families. For more information, call your local Head Start Center or visit the Florida Head Start Web site at http://www. floridaheadstart.org/.

\section{Public School}

You do not necessarily have to have custody of your grandchildren to enroll them in public school. However, each school district has its own requirements, so it is best to call the school before you attempt to enroll your grandchild.

Registering your grandchild in public school is an important task. There are several documents you will need to have with you to register your grandchild for public school. You will need to show proof of:

- your residence

- your grandchild's date of birth

- your grandchild's record of immunizations and physical exams

- custody documentation (or other proof of guardianship as required by the school district)

- $\quad$ any previous school records

If your grandchild has attended public school before, these documents may be on file at his previous school.

\section{Afterschool Care for School-age Children}

If you continue to work while raising your grandchild, you may be faced with the possibility of needing after-school care. After school care can be found at:

- Schools

- Boys and Girls Clubs

- YMCA

- Places of Worship

- Parks and Recreation Department

- Private Centers

- Nonprofit Organizations

1. This document, adapted from the December version of FCS2188, is FCS2188c, one of a series of the Department of Family, Youth and Community Sciences, Florida Cooperative Extension Service, Institute of Food and Agricultural Sciences (IFAS), University of Florida. Publication date: August 2009. Please visit the EDIS Web site at http://edis.ifas.ufl.edu.

2. Maisie Ross, Family and Consumer Sciences, West Palm Beach County Extension, 559 N. Military Trail, West Palm Beach, 33415; Larry F. Forthun, Ph.D., assistant professor, Department of Family, Youth and Community Sciences, Institute of Food and Agricultural Sciences, University of Florida, Gainesville, FL 32611; Millie Ferrer-Chancy, Ph.D., interim dean, Florida Cooperative Extension Service, University of Florida; and, Angela Falcone, former FYCS graduate student of University of Florida. 